\title{
Reduction of cell mediated immunity in patients with genital warts of long duration
}

\author{
G AVGERINOU, S GEORGALA, A THEODORIDIS, A VARELTZDIS, AND J STRATIGOS \\ From the Department of Dermatology, A Sygros Hospital, University of Athens, Athens, Greece
}

SUMMARY Cell mediated immunity was studied by a leucocyte migration inhibition assay and by tuberculin and dinitrochlorobenzene skin tests in 30 patients with recurrent genital warts and in 34 healthy people (with no history of genital warts) who served as controls. Migration inhibition was significantly less in patients suffering from recurrences for more than one year than in controls $(p<$ $0.001)$. Dinitrochlorobenzene and tuberculin sensitivity were also found to be impaired in those with infection of long duration $(\mathrm{p}<0.001)$.

\section{Introduction}

Infection with genital warts is a common condition. Serological and epidemiological studies have shown that human papillomavirus (HPV) is responsible for genital wart infections. ${ }^{12}$ Competence of cell mediated immunity in patients with warts has been assessed by measuring in vitro response to phytohaemagglutinin and purified protein derivative of tuberculin. Patients with genital warts were found to be less responsive than a control group, and this deficiency was related to the duration of genital wart infection. ${ }^{3}$ The suggestion has been made that cell mediated immune responses play a part in achieving successful resolution of genital wart virus infection..$^{3-5}$ If that is so, then possession of a competent cell mediated immune system would be a prerequisite for the successful resolution of genital warts in a patients. ${ }^{6-8}$ As regression or resolution of genital warts may be protracted in some patients, they may have a different specific or non-specific cell mediated immune function from that of the general population.-5

We undertook the present study to test this possibility by comparing the cell mediated immune responses in patients with genital warts of varying duration with those of a control group. Three tests of such responses were studied; phytohaemagglutinin in vitro and skin tests with purified protein derivative and dinitrochlorobenzene in vivo.

Address for reprints: Dr A Theodorides, Department of Dermatology, A Sygros Hospital, University of Athens, Athens, Greece

Accepted for publication 23 December 1985

\section{Patients, materials, and methods}

We investigated 30 patients ( 17 men and 13 women) aged 17 to 60 (mean 30) years. All patients had a history of genital warts of variable duraton. No patient suffered from any disease, such as the acquired immune deficiency syndrome (AIDS) or lymphoma, or was taking drugs, such as chemotherapeutic agents, that could be responsible for the reduction of cellular immunity. Fourteen patients (group 1) gave a history of having had warts for less than one year, 10 (group 2) had had warts for one to three years, and six (group 3) for more than three years.

The control group consisted of 34 healthy people ( 23 men and 11 women) aged 24 to 60 (mean 30) years, mainly from the hospital staff.

\section{LEUCOCYTE MIGRATION INHIBITION TEST}

The leucocyte migration inhibition test was used as an in vitro measure of cell mediated immunity. The test was carried out according to the method described by Bendixen and Soborg, ${ }^{9}$ as modified by Federlin et al. ${ }^{10}$ Phytohaemagglutinin was used as an antigen at a concentration of $0.025 \mathrm{~g} / 1$ of culture medium. The area of migration was assessed by projecting the culture chambers and then their contents on a screen (piece of white paper) and tracing the circumference of the "fan" of cells, which was then accurately cut and weighed. The migration inhibition index was assessed as follows:

weight in presence of phytohaemagglutinatinin

weight of migration area in control chambers An index of less than 0.8 was considered to show appreciable migration inhibition. 


\section{PURIFIED PROTEIN DERIVATIVE SKIN TEST}

The standard solution of purified protein derivative (PPD RT 23 with $0.005 \%$ polysorbate (Tween) 80) from Statents Seruministitut, Copenhagen, was used for this skin test. ${ }^{11} 12 \mathrm{We}$ injected intradermally $0.1 \mathrm{ml}$ IU (equivalent to $0.02 \mu \mathrm{g}$ of PPD), and read the results after 48 hours. Patients with induration of less than 5 $\mathrm{mm}$ in diameter were considered to be Mantoux negative. An induration of between 5 and $12 \mathrm{~mm}$ in diameter was arbitrarily considered to be a weak Mantoux positive reaction, whereas larger indurations were considered to be strongly positive.

\section{DINITROCHLOROBENZENE SKIN TEST}

Dinitrochlorobenzene reactivity was assessed using the method described by Catalona et $a l^{13}$ and Strauss et al. ${ }^{14}$ Doses of 50 and $2000 \mu \mathrm{g}$ dinitrochlorobenzene in $0.1 \mathrm{ml}$ of acetone were applied to $3 \mathrm{~cm}$ of the forearm and upper arm, respectively. After 14 days patients responding to both test doses were recorded as giving grade 4 responses. If a flare occurred at the higher dose only, the reaction was recorded as a grade 3 response. If after 14 days no reaction occurred, an additional challenge dose of $50 \mu \mathrm{g}$ dinitrochlorobenzene was applied to the other forearm. If a conspicuous reaction was seen it was assessed as grade 2 . In the case of a negative reaction, a punch biopsy specimen was taken and examined histologically for evidence of a delayed hypersensitivity reaction. If it was microscopically positive the reaction was considered to be grade 1 . If the reaction was negative it was recorded as grade 0. test.

Statistical analyses were done using Student's $t$

\section{Results}

The results were recorded for the three groups, according to the duration of the infection, and for the fourth (control) group. The differences between the groups were evaluated statistically.

\section{LEUCOCYTE MIGRATION INHIBITION ASSAY}

Table I shows that leucocyte migration was significantly less in patients in group 2 than in group 1 $(p<0.001)$ and significantly less in patients in group 3 than in group $2(0.001<\mathrm{p}<0.01)$. No difference in migration was found between group 2 and the controls $(p>0 \cdot 1)$. The mean migration index was higher in patients with a longer history of genital warts. In addition, almost all patients with a migration index higher than 0.3 had had genital warts for longer than one year.

\section{PURIFIED PROTEIN DERIVATIVE SKIN TEST}

The figure shows that in group 3 , the tuberculin type hypersensitivity was less than in group 2 , and much
TABLE I Results of leucocyte migration inhibition assay analysed according to duration of genital wart infection

\begin{tabular}{llll}
\hline Group & $\begin{array}{l}\text { Duration } \\
\text { (years) of } \\
\text { infection }\end{array}$ & $\begin{array}{l}\text { No of } \\
\text { patients }\end{array}$ & $\begin{array}{l}\text { Mean (SD) } \\
\text { migration } \\
\text { inhibition index }\end{array}$ \\
\hline 1 & 1 & 14 & $0.20(0.06)$ \\
2 & $1-3$ & 10 & $0.40(0.05)$ \\
3 & $>3$ & 6 & $0.60(0.01)$ \\
Controls & & 34 & $0.22(0.07)$ \\
\hline
\end{tabular}

Migration inhibition index $=$ migration area with phytohaemagglutinin $\div$ area in control chambers in leucocyte migration inhibition test.

less than in group 1. No difference in skin test reactivity was found between group 1 patients and the controls.

\section{DINITROCHLOROBENZENE SKIN TEST}

Table II shows that significantly ( $p<0.001)$ less reactivity was found in group 2 than in group 1 and that the reactivity of group 3 was significantly $(p<0.01)$ less than that of group 2. No difference was found between group 1 and the control group. It thus became apparent that the dinitrochlorobenzene skin test reactivity was reduced with longer durations of recurrent genital wart
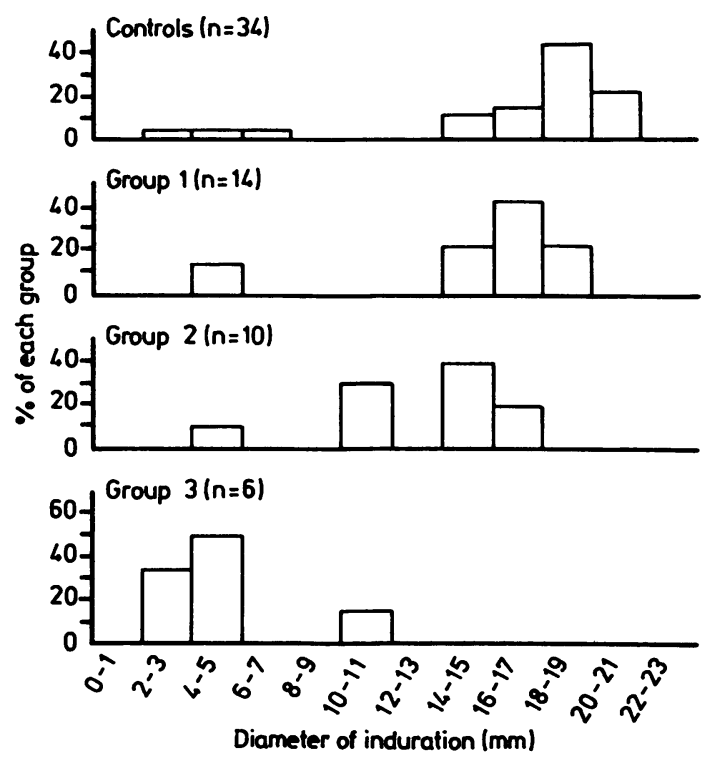

FIGURE Tuberculin sensitivity (size of induration 48 hours after intradermal injection with $0.02 \mu \mathrm{g}$ purified protein derivative (PPD) of tuberculin) in 34 controls and 30 patients with genital warts. Duration of infection: < one year (group 1), 1-3 years (group 2), > three years (group 3). 
TABLE II Results of dinitrochlorobenzene (DNCB) skin test according to duration of genital wart infection

\begin{tabular}{|c|c|c|c|c|}
\hline Group & $\begin{array}{l}\text { Duration } \\
\text { (years) of } \\
\text { infection }\end{array}$ & $\begin{array}{l}\text { No of } \\
\text { patients }\end{array}$ & $\begin{array}{l}\text { DNCB } \\
\text { grade }\end{array}$ & $\begin{array}{l}\text { Mean }(S D) \\
\text { DNCB } \\
\text { grade }\end{array}$ \\
\hline 1 & 1 & $14\left\{\begin{array}{l}9 \\
3 \\
2\end{array}\right.$ & $\left.\begin{array}{l}4 \\
3 \\
2\end{array}\right\}$ & $3.5(0.76)$ \\
\hline 2 & $1-3$ & $10\left\{\begin{array}{l}7 \\
3\end{array}\right.$ & $\left.\begin{array}{l}2 \\
3\end{array}\right\}$ & $2 \cdot 3(0 \cdot 48)$ \\
\hline 3 & $>3$ & $6\left\{\begin{array}{l}4 \\
2\end{array}\right.$ & $\left.\begin{array}{l}1 \\
2\end{array}\right\}$ & $1 \cdot 3(0.53)$ \\
\hline Controls & & $34\left\{\begin{array}{l}22 \\
12\end{array}\right.$ & $\left.\begin{array}{l}4 \\
3\end{array}\right\}$ & $3.7(0.48)$ \\
\hline
\end{tabular}

DNCB grade $4=$ reaction to $50 \mu \mathrm{g}$ and $2000 \mathrm{mg}$ DNCB; grade $3=$ reaction to higher dose only; grade $2=$ reaction to additional challenge of $50 \mu \mathrm{g}$ after no initial reaction; grade $1=$ no clinical reaction, but punch biopsy specimen microscopically positive.

\section{Discussion}

Genital warts are defined as non-keratotic fleshy lesions occuring in moist areas of the body at the junction of the squamous epithelium and mucous membrane, and should be distinguished from common warts that may also occur in the genital area. ${ }^{15}$ There are no morphological differences between the virus of ordinary skin warts and that causing genital warts, but there are antigenic differences as shown by one way cross reactivity between genital and skin wart antibodies. ${ }^{16-18}$

Genital warts are common, and in general they probably develop not because of any significant immune or other deficiency, but rather as a result of exposure to the virus..$^{3-5}$ There is, however, noticable variation in the ability of patients to control and eradicate the infection, and some patients have what appear to be very resistant warts. ${ }^{57}$ Observations that patients with immunodeficiency have an increased incidence of HPV infection ${ }^{36-81519}$ show that cell mediated immunity plays a part in genital wart regression.

In the study published here cell mediated immunity correlated well with the duration of genital wart infection. From the results of this study, we consider that delayed hypersensitivity, expressed both as tuberculin and contact sensitivity, decreases with the duration of infection.

The result of the migration inhibition assay, which represents an in vitro correlation of cell mediated immunity, paralleled those of the in vivo tests. Thus significantly higher migration indices were found in patients with infection of long duration than in those with short duration infection. It is interesting to note that within the first year delayed hypersensitivity was found to be unimpaired. Thus the effect of the suppressed delayed hypersensitivity seems to become important after at least one year of infection.

These findings indicate that non-specific cell mediated immune responses are to some extent defective in patients with a long history of genital wart infection. We therefore postulate that the lack of a fully cell mediated immune system may well be the reason that the genital warts of some patients are so difficult to eradicate.

\section{References}

1. Ogilvie MM. Serological studies with human papova (wart) virus. J Hyg (Lond) 1970;68:479-82.

2. Cubie HA. Serological studies in student population prone to infection with human papilloma virus. $J$ Hyg (Lond) 1972;70:677-81.

3. Morisson WI. Cell-mediated immune responses in patients with warts. Br J Dermatol 1975;93:553-6.

4. Morisson WL. In vitro assay of cell-mediated immunity to human wart antigen. Br J Dermatol 1974;90:531-4.

5. Reid TM, Fraser NG, Kernohan IR. Generalized warts and immune deficiency BrJ Dermatol 1976;95:559-64.

6. Korand FC, Dehmel EM, Kahn C, Penn I. Cutaneous complication in immunosuppressed renal homograft recipients. JAMA 1974;221:419-24.

7. Perry TL, Harman L. Warts in diseases with immune defects. Cutis 1974;13:359-62.

8. Spencer ES, Andersen HK. Clinically evident, non terminal infections with herpesviruses and the wart virus in immunosuppressed renal allograft recipients. Br Med J 1970;iii:251-4.

9. Bendixen G, Soborg M. A leucocyte migration technique for in vitro detection of cellular (delayed type) hypersensitivity. Dan Med Bull 1969;16:1-4.

10. Federlin K, Maini RN, Russel AS, Dumode DC. A micro method for peripheral leucocyte migration in tuberculin sensitivity. J Clin Pathol 1971;24:533-6.

11. Bentzon JM. Effect of certain infectious diseases on tuberculin allergy. Tubercle 1953;34:34-5.

12. Viac J, Thivolet J, Chardonnet Y. Specific immunity in patients suffering from recurring warts before and after repetitive intradermal tests with human papilloma virus. $\mathrm{Br} J$ Dermatol 1977;97:365-70.

13. Catalona WJ, Taylor PT, Robson AS, Chretien PB. A method for dinitrochlorobenzene contact sensitization. $N$ Engl J Med 1972;286:399-401.

14. Strauss $\mathbf{G H}$, Greaves $M$, Price $M$, Bridges BA, Half-Smith $P$, Velba-Briffa D. Inhibition of delayed hypersensitivity reaction in skin (DNCB test) by 8 methoxypsoralen photochemotherapy. Lancet 1980 ; i:556-9.

15. Felman YM. Condylomata accuminata. Cutis 1984;33:118 20.

16. Almeida JD. Virologic aspects of genital warts. In: Catterall RD, Nicol CS, eds. Sexually transmitted diseases. London: Academic Press, 1976:179-83.

17. Oriel JD. Genital warts: the clinical problems. In: Catterall RD, Nicol CS, eds. Sexually transmitted diseases. London: Academic Press, 1976:186-192.

18. Oriel JD. Natural history of genital warts. British Journal of Venereal Diseases 1971;47:1-13.

19. Thivolet J, Cencig MC, Clandy A. Frequence des verrues apres transplantation renale. Lyon: Compterendus Seminaire Fondation Merieux, 1975. 